\title{
PENINGKATAN PENGETAHUAN TENTANG HIPERTENSI PADA LANSIA DI POSYANDU LANSIA DUKUH GANTUNGAN DESA MAKAMHAJI KARTASURA SUKOHARJO
}

\author{
Domas Fitria Widyasari dan Anika Candrasari \\ Fakultas Kedokteran \\ Universitas Muhammadiyah Surakarta
}

\begin{abstract}
Hypertension is a degenerative disease that affects nearly $25 \%$ of the population around the world today and is a risk factor of cardiovascular disease. Geriatric (elderly) in Indonesia is a group of residents that become the focus of attention because of the number of elderly is increase, and brought variety of health problems. Hypertension can be treated with pharmacological treatment and lifestyle improvements with the correct knowledge based. Hypertension will be a problem if elderly people are not guided and equipped with proper knowledge regarding the health of hypertension.SimakBaca secara fonetik The purpose of this activity is to improve knowledge and attitudes about hypertension of rural elderly in Gantungan Makamhaji Kartasura Sukoharjo. Health education about hypertension is given by lectures and discussion method. Evaluation used questionnaire that consist of 35 questions, which was considered one if the answer is correct and zero if the answer is incorrect using pre-test and post-test about hypertension The results obtained by descriptive mean. There is an increasing value of knowledge average about hypertension after administration of education from 4.46 to 13.97 and attitudes average about hypertension from 3.49 to 9.90 Based on the result, health education institutions should cooperate with health service institutions to give information about hypertension through periodic health education. And government health institutions should expand health education focusing on elderly through Posyandu Lansia.
\end{abstract}

Kata kunci: hipertensi, lansia, pengetahuan, sikap

\section{PENDAHULUAN}

\section{Analisis Situasi}

Lansia (Lanjut Usia) adalah penduduk yang berusia 60 tahun ke atas (Statistik Indonesia, 2010). Penggolongan lansia menurut Depkes dibagi menjadi tiga kelompok yakni kelompok lansia dini (55 - 64 tahun), kelompok lansia (65 tahun ke atas), dan lansia resiko tinggi (lebih dari 70 tahun).

Indonesia adalah termasuk negara yang memasuki era penduduk berstruktur lanjut usia (aging structured population) karena jumlah penduduk yang berusia 60 tahun ke atas sekitar 7,18\%. Badan Perencanaan dan Pembangunan Nasional (BAPPENAS) memperkirakan pada 2025, lebih dari seperlima penduduk Indonesia adalah orang lanjut usia (Megarani, 2007). Lansia merupakan kelompok penduduk yang menjadi fokus perhatian para ilmuwan, masyarakat, dan pemerintah karena membawa berbagai permasalahan yang harus diantisipasi dan dicarikan jalan keluarnya, termasuk bidang kesehatan(Cunha, 2001). 
Hipertensi merupakan penyakit degeneratif yang hampir diderita sekitar 25\% penduduk dunia dewasa (Adrogué \& Madias, 2007). Hipertensi didefinisikan sebagai tekanan darah sistolik >140 mm Hg atau tekanan diastolik $>90 \mathrm{~mm} \mathrm{Hg}$ (National Heart Lung \& Blood Insitute, 2003). Prevalensi utama hipertensi pada kulit hitam, pria dan pada orang tua (August, 2003). Insidensi hipertensi meningkat seiring bertambahnya usia, sekitar $60 \%$ dari semua kematian prematur diakibatkan oleh hipertensi terjadi di antara pasien dengan hipertensi ringan (Fisher dan Gordon, 2005).

Prevalensi hipertensi diprediksi meningkat $60 \%$ pada tahun 2025, yaitu sekitar 1.56 juta orang penderita. Hal ini merupakan faktor risiko dari penyakit kardiovaskuler dan bertanggung jawab terhadap kebanyakan kematian di dunia. Hipertensi primer atau yang dikenal dengan hipertensi essensial atau idiopatik merupakan kasus hipertensi terbanyak, yaitu sekitar 95\% dari kejadian hipertensi secara keseluruhan (Adrogué \& Madias, 2007). Berdasarkan penelitian WHO-Comunity Study of the Elderly Central Java menemukan bahwa hipertensi dan penyakit kardiovaskuler merupakan penyakit kedua terbanyak yang diderita lansia setelah artritis, yaitu sebesar 15,2\% dari 1203 sampel (Nugroho, 2000).

Tingkat pendidikan, komunikasi dan informasi, kebudayaan, dan pengalaman pribadi seseorang akan mempengaruhi pengetahuan dan sikap tentang kesehatan Dengan mendapatkan infomasi yang benar, diharapkan lansia mendapat bekal pengetahuan yang cukup untuk dapat melaksanakan pola hidup sehat dan dapat menurunkan risiko penyakit degeneratif terutama hipertensi dan penyakit kardiovaskular (Notoatmodjo, 2003).

Posyandu lansia adalah pos pelayanan terpadu untuk masyarakat usia lanjut di suatu wilayah tertentu yang sudah disepakati, yang digerakkan oleh masyarakat dimana mereka bisa mendapatkan pelayanan kesehatan.
Posyandu Lansia Menur IV berlokasi di Dukuh Gantungan Desa Makamhaji Kartasura Sukoharjo. Posyandu ini dibina oleh Puskesmas Kartasura dan memiliki program pemeriksaan kesehatan lansia. Jumlah anggota di posyandu lansia ini tercatat 100 orang dengan pendamping kader sebanyak 20 orang. Dalam menjalankan program kesehatan,osyandu ini mengadakan penyuluhan kesehatan namun pelaksanaan penyuluhan tidak rutin setiap bulan.

Diharapkan kegiatan pengabdian ini dapat bermanfaat bagi masyarakat khususnya lansia di Dukuh Gantungan untuk meningkatkan pengetahuan dan sikap lansia mengenai hipertensi serta memperbaiki persepsi dan pola hidup lansia.Lansia diharapkan untuk dapat menjalankan pola hidup sehat didasari dengan pengetahuan yang cukup sehingga kesehatan dan kesejahteraan hidup lansia akan menjadi lebih baik.

\section{Perumusan Masalah}

Permasalahan tentang hipertensi di usia lansia sudah merupakan permasalahan yang sukar dikendalikan. Hal ini dilatarbelakangi oleh beberapa faktor yaitu : masih rendahnya pemahaman lansia tentang isu-isu kesehatan dan pola hidup yang benar, rendahnya pemahaman lansia tentang kesehatan di usia tua karena mereka tidak memperoleh informasi yang cukup dan benar tentang kesehatan ketika memasuki usia tua, dan selain itu lansia jarang tersentuh pelayanan kesehatan geriatri (informasi dan pelayanan medis).

Permasalahan di usia lansia memang berhubungan dengan pola hidup yang sejak lama dilakukan di dalam sehari-hari. Lansia kadang merasa kurang memperhatikan masalah kesehatannya dan terutama tekanan darah yang seringkali dianggap sepele oleh para lansia. Pola perilaku hidup yang sejak lama dijalani oleh lansia kadang kurang berdasarkan pada pendidikan dan pengetahuan tentang kesehatan yang benar 
Apabila lansia memperoleh informasi tentang kesehatan terutama tentang hipertensi hanya melalui pengalaman orang per orang dan tidak diimbangi dengan informasi yang benar dan akurat khususnya masalah hipertensi, maka kemungkinan kesehatan lansia terutama tekanan darahnya akan tidak diperhatikan dengan baik. Padahal tekanan darah yang tidak terkontrol merupakan faktor risiko penyakit-penyakit kardiovaskuler yang berbahaya dan tentunya akan memperburuk kualitas kesehatan lansia. Selain itu, lansia dini juga harus mempersiapkan diri menghadapi kondisi lansia yang nantinya akan dihadapi di tahun-tahun berikutnya, sehingga kondisi penyakit kardiovakuler dapat dicegah secara dini.

Dari identifikasi masalah tersebut dibuat perumusan masalah bahwa dengan pemberian pendidikan kesehatan tentang hipertensi pada lansia dan pra lansia maka akan meningkatkan pengetahuan dan memperbaiki sikap tentang hipertensi sehingga lansia akan dapat menjaga kesehatan diri dengan baik sehingga akan terhindar dari penyakit-penyakit kardio-vaskuler. Selain itu bagi lansia yang sudah tekena penyakit kardiovaskuler dapat mempertahankan kualitas kesehatan dengan baik.

\section{Tinjauan Pustaka}

Pendidikan kesehatan merupakan suatu bentuk tindakan mandiri keperawatan untuk membantu klien baik individu, kelompok, maupun masyarakat dalam mengatasi masalah kesehatannya melalui kegiatan pembelajaran (Notoatmodjo, 2003). Pendidikan kesehatan pada dasarnya adalah proses mendidik individu/masyarakat supaya mereka dapat memecahkan masalah kesehatan yang dihadapinya (Sarwono, 2004). Pendidikan kesehatan bertujuan untuk meningkatkan status kesehatan, mencegah timbulnya penyakit dan bertambahnya masalah kesehatan, mempertahankan derajat kesehatan yang sudah ada, memaksimalkan fungsi dan peran pasien selama sakit, serta membantu pasien dan keluarga untuk mengatasi masalah kesehatan(Notoatmodjo, 2003).

Pendidikan kesehatan memiliki unsur masukan /input berupa perilaku pemakai sarana kesehatan dan petugas kesehatan yang setelah diolah dengan teknik pendidikan tertentu akan menghasilkan output berupa perubahan perilaku kesehatan masyarakat sasaran yang sesuai dengan harapan atau tujuan kegiatan itu. Pendidikan memang bukanlah satu-satunya cara mengubah perilaku individu/kelompok. Menurut Notoatmodjo dan Sarwono, ada tiga macam cara mengubah perilaku, yaitu:

a. Menggunakan kekuasaan/ kekuatan

b. Memberikan informasi

c. Diskusi dan Partisipasi (Sarwono, 2004).

Persuasi di bidang pendidikan kesehatan akan dapat memberikan perubahan perilaku yang sesuai dengan harapan. Untuk dapat merubah perilaku, harus dipertimbangkan faktor yang mempengaruhi perilaku kesehatan yaitu berupa pengetahuan, pengalaman, kepercayaan, kebudayaan, sikap, dll. Hubungan antara pengetahuan, sikap dan praktek terlihat dalam model KAP (knowledge, attitude, practice) yang menunjukkan bahwa informasi/pengetahuan yang benar akan mempengaruhi sikap dan nantinya akan mengubah perilaku/praktek (Kiger, 2004)

Model perubahan perilaku yang sekarang masih dianut adalah model perubahan perilaku dari Green yang dikembangkan oleh Lawrence Green yang mengatakan bahwa kesehatan individu/ masyarakat dipengaruhi oleh dua faktor pokok yaitu faktor perilaku dan non perilaku. Faktor perilaku ditentukan oleh tiga kelompok faktor yaitu faktor presisposisi (pengetahuan individu, sikap, kepercayaan, tradisi, norma sosial, dan unsur lain yang terdapat dalam individu dan masyarakat), pendukung (tersedianya sarana pelayanan kesehatan dan kemudahan untuk mencapainya), dan pendorong (sikap dan perilaku 
petugas kesehatan). Pendidikan kesehatan mempunyai peranan penting dalam mengubah dan menguatkan ketiga kelompok faktor itu agar searah dengan tujuan kegiatan sehingga menimbulkkan perilaku positif dari masyarakat terhadap program tersebut dan terhadap kesehatan pada umumnya (Sarwono, 2004).

Pengetahuan merupakan hasil tahu yang terjadi setelah orang melakukan penginderaan terhadap suatu objek tertentu. Pengetahuan merupakan domain yang sangat penting untuk terbentuknya tindakan seseorang. Pengetahuan memiliki 6 tingkatan yaitu: tahu (know), memahami (comprehension), aplikasi (application), analisis (analysis), sintesis (synthesis), dan evaluasi (evaluation). Sedangkan sikap adalah reaksi atau respon seseorang yang masih tertutup terhadap suatu stimulus atau objek, manifestasi sikap tidak dapat langsung dilihat tetapi hanya dapat ditafsirkan terlebih dahulu dari perilaku yang tertutup. Sikap juga merupakan reaksi yang bersifat emosional terhadap stimulus sosial (Notoatmodjo, 2003).

Pendidikan kesehatan pada lansia harus dioptimalkan untuk memberikan jalan keluar pada berbagai permasalahan lansia di bidang kesehatan. Selain itu, jumlah lansia yang terus meningkat harus diimbangi dengan pengetahuan dan kesadaran kesehatan yang benar sehingga kesejahteraan lansia dapat tercapai (Cunha, 2001). Statistik Indonesia (2010) mendefinisikan bahwa lansia (Lanjut Usia) adalah penduduk yang berusia 60 tahun ke atas. Penggolongan lansia menurut Depkes dikutip dari Azis (1994) menjadi tiga kelompok yakni kelompok lansia dini (55 - 64 tahun), kelompok lansia (65 tahun ke atas), lansia resiko tinggi (lebih dari 70 tahun). Indonesia adalah termasuk negara yang memasuki era penduduk berstruktur lanjut usia (aging structured population) karena jumlah penduduk yang berusia 60 tahun ke atas sekitar 7,18\% (Megarani, 2007).
Peningkatan jumlah lansia akan memberi dampak pada peningkatan kebutuhan sarana prasarana kesehatan bagi lansia. Salah satu layanan kesehatan lansia yang efektif dalam memberikan pelayanan kesehatan lansia dan diselenggarakan melalui program Puskesmas adalah Posyandu Lansia. Salah satu kegiatan posyandu lansia adalah pemberian penyuluhan tentang masalah kesehatan lansia termasuk tentang penyakit-penyakit degeneratif yang salah satunya adalah hipertensi.

Hipertensi merupakan penyakit degeneratif yang ditandai dengan peningkatan tekanan sistolik $>140 \mathrm{mmHg}$ dan diastolik $>80 \mathrm{mmHg}$ (National Heart Lung \& Blood Insitute, 2003). Pada lansia, tekanan darah akan naik secara bertahap. Elastisitas jantung pada orang berusia 70 tahun akan menurun sebesar 50\% dibanding dengan orang berusia 20 tahun.

Tabel 1.

Klasifikasi Tekanan Darah menurut JNC VII

\begin{tabular}{|l|l|l|}
\hline $\begin{array}{l}\text { Klasifikasi } \\
\text { Tekanan } \\
\text { Darah }\end{array}$ & $\begin{array}{l}\text { Tekanan } \\
\text { Systole } \\
(\mathrm{mmHg})\end{array}$ & $\begin{array}{l}\text { Tekanan } \\
\text { Diastole } \\
(\mathrm{mmHg})\end{array}$ \\
\hline Normal & $<120$ & $<80$ \\
\hline Prehipertensi & $120-139$ & $80-90$ \\
\hline Kategori I & $140-159$ & $90-99$ \\
\hline Kategori II & $\geq 160$ & $\geq 100$ \\
\hline
\end{tabular}

(National Heart Lung \& Blood Insitute, 2003)

Hipertensi menjadi masalah pada lansia karena sering ditemukan dan menjadi faktor risiko stroke, payah jantung, dan penyakit jantung koroner. Lebih dari separuh kematian di atas usia 60 tahun disebabkan oleh penyakit jantung dan serebrovaskuler (Nugroho, 2000). Insidensi hipertensi meningkat seiring bertambahnya usia, dengan $50 \%$ hingga $60 \%$ dari orang berusia 60 tahun memiliki tekanan darah di atas 140 atau $90 \mathrm{mmHg}$. Sekitar $60 \%$ dari semua kematian prematur diakibatkan oleh 
hipertensi terjadi di antara pasien dengan hipertensi ringan (Fisher dan Gordon, 2005).

Alasan pasti mengapa sebagian besar orang menderita hipertensi tidak diketahui. Meskipun demikian sekitar 2\% dari pasien hipertensi ditemukan penyebabnya. Sebab dari hipertensi termasuk penyakit pada ginjal dan kelenjar adrenal. Orang dengan tekanan darah tinggi oleh sebab ini mungkin akan mengalami derajat tekanan darah yang tinggi sekali. Penyakit dari kelenjar tiroid juga menyebabkan peningkatan tekanan darah. Koartkasio aorta suatu penyakit congenital menyempitnya aorta di dada dapat dikaitkan dengan peningkatan tekanan darah pada tangan dan penurunan tekanan darah pada kaki. Penting untuk dimengerti sekitar $98 \%$ orang dengan hipertensi tidak ditemukan sebabnya (Braunwald et al, 2001).

Hipertensi dapat diakibatkan oleh perilaku/pola hidup yang tidak baik. Faktorfaktor dan perilaku yang dapat menjadi penyebab hipertensi yaitu:

a. Usia: hipertensi banyak diderita oleh orang tua dimana penelitian menunjukkan bahwa orang berusia 55 tahun dengan tekanan darah yang sebelumnya normal, 90\%-nya akan mengalami kenaikan tekanan darah di tahun-tahun kehidupan berikutnya.

b. Asupan Sodium yang melebihi normal: asupan sodium terhadap kenaikan tekanan darah sekarang ini banyak sekali diteliti. Hal ini berkaitan dengan sifat Sodium yang menyebabkan retensi cairan di dalam tubuh. Hipertensi jarang terjadi pada intake sodium yang rendah yaitu sekitar $<60 \mathrm{mmol} / \mathrm{hari}$.

c. Kurangnya diit vegetarian (sayur dan buah): Cereal, buah, dan sayuran mengandung banyak kandungan kalium dan rendah sodium. Adanya banyak kandungan kalium dapat menurunkan tekanan darah.

d. Intake lemak berlebih: Intake lemak berisiko meningkatkan pembentukan atherosklerosis yang akan menyebabkan dinding pembuluh darah mengeras dan menyebabkan tekanan darah dapat meningkat.

e. Intake alkohol: Beberapa studi menunjukkan hubungan linier yang positif antara tekanan sistolik dan diastolik dengan pengkonsumsian alkohol.

f. Merokok: Penelitian menunjukkan bahwa orang yang merokok berisiko lebih besar menderita penyakit hipertensi dibandingkan yang tidak merokok.

g. Stress: Nyeri, marah, keingintahuan berlebih, ketakutan, kegembiraan dan rasa malu menyebabkan tekanan darah akan meningkat (National Heart Lung \& Blood Insitute, 2003)

Hipertensi dapat mengakibatkan kerusakan pembuluh darah, meningkatkan risiko sakit jantung dan stroke. Hipertensi juga dapat mengakibatkan gagal jantung, penurunan efisiensi fungsi ginjal, dll. (Mansjoer et al, 2001). Hipertensi dapat dicegah dengan pola hidup sehat dan mengendalikan faktor risiko hipertensi seperti: mempertahankan berat badan ideal, tidak merokok, tidak minum kopi, tidak mengkonsumsi alkohol, latihan aerobik, modifikasi tingkah laku, dan penghentian obat yang meningkatkan tekanan darah (obat pengatur kelahiran, kortikosteroid, mineralokortikoid, dan lain-lain) (National Heart Lung \& Blood Insitute, 2003).

\section{Tujuan dan Manfaat}

Tujuan umum pengabdian ini adalah untuk meningkatkan pengetahuan dan sikap lansia tentang hipertensi di desa Makamhaji Kartasura Sukoharjo. Secara khusus, setelah diberikan pengetahuan tentang hipertensi, maka lansia mampu memiliki pengetahuan yang benar dan mengetahui dampak negatif hipertensi dan penyakit kardiovaskuler sehingga dapat menghindarinya. Manfaaat pengabdian ini bagi lansia desa Makamhaji Kartasura Sukoharjo: dapat memperoleh 
pengetahuan dan keterampilan dasar mengenai hipertensi yang benar, bagi pihak Posyandu Lansia: dapat dijadikan dasar dalam perencanaan program pendidikan kesehatan dan pemeliharaan kesehatan bagi lansia, dan bagi intansi terkait: dapat menjadi masukan dalam rangka perencanaan program kesehatan lansia melalui upaya peningkatan promosi kesehatan yang mencakup sasaran lansia.

\section{METODE PLAKSANAAN}

Metode yang dilakukan dengan memberikan ceramah langsung dengan handout dan slide gambar yang menarik serta tanya jawab tentang hipertensi. Evaluasi kegiatan dilakukan dengan memberikan pertanyaan melalui kuesioner yang terdiri dari 35 pertanyaan yaitu 20 pertanyaan pengetahuan dan 15 pertanyaan sikap yang diberikan sebelum dan sesudah pemberian materi untuk mengetahui peningkatan pemahaman lansia tentang materi yang disampaikan.

\section{HASIL DAN PEMBAHASAN}

Pengabdian masyarakat ini dilaksanakan pada tanggal 20 Februari 2010 di Posyandu Dukuh Gantungan Makamhaji Kartasura Sukoharjo. Sebanyak 39 lansia yang diwawancarai secara terstruktur dengan menggunakan kuesioner yang berisi pengetahuan dan sikap responden (yang selanjutnya disebut dengan pengetahuan dan sikap sebelum penyuluhan), kemudian diberikan pendidikan kesehatan berupa penyuluhan kepada lansia yang berisi definisi, penyebab, akibat, komplikasi dan penanganan hipertensi. Setelah pengetahuan diwawancarai lagi tentang pengetahuan dan sikap (yang selanjutnya disebut dengan pengetahuan dan sikap setelah penyuluhan). Pertanyaan pengetahuan dan sikap sebelum dan setelah penyuluhan dibuat sama dengan harapan bahwa dengan diberikannnya penyuluhan maka akan terjadi peningkatan pengetahuan dan sikap.

Lansia yang turut serta dalam pengabdian ini sebagian besar berpendidikan rendah (lulusan SD 51\%), memiliki pekerjaan ibu rumah tangga (51,3\%) dan rata-rata umur responden 66,59 tahun. Berdasarkan data si atas, maka metode penyampaian materi pengetahuan dan sikap dipilih dengan penyuluhan langsung yang disampaikan secara interaktif dan menggunakan bahasa awam serta menggunakan gambar, foto, dan slide yang menarik. Penyuluhan kesehatan merupakan kegiatan pendidikan kesehatan yang dilakukan dengan menyebarluaskan pesan dan menanamkan keyakinan. Penyuluhan kesehatan bertujuan mengubah perilaku kurang sehat menjadi perilaku sehat. Media penyampaian penyuluhan dibuat dengan slide yang menarik yang disesuaikan dengan jenis sasaran, tingkat pendidikan, aspek yang ingin dicapai, metode yang digunakan dan sumber yang ada (Maulana, 2009). Pengumpulan informasi tentang pengetahuan dan sikap responden terhadap hipertensi dilakukan dengan wawancara satu per satu antara peneliti dengan responden. Hal ini dilakukan untuk memudahkan penangkapan informasi pada lansia dikarenakan lansia mengalami degenerasi pada fungsi organ tubuhnya

\section{Pengetahuan tentang Hipertensi}

Pengetahuan merupakan hasil tahu yang terjadi setelah orang melakukan penginderaan terhadap suatu objek tertentu. Pengetahuan merupakan domain yang sangat penting untuk terbentuknya tindakan seseorang. Hasil penelitian membuktikan bahwa perilaku yang didasari oleh pengetahuan akan lebih langgeng dari pada yang tidak didasari pengetahuan (Notoatmodjo, 2003). 
Tabel 2.

Deskripsi Data Skor Pengetahuan

\begin{tabular}{|l|c|c|c|c|c|}
\hline \multicolumn{1}{|c|}{ Kondisi } & $\begin{array}{c}\text { Rata- } \\
\text { rata }\end{array}$ & $\begin{array}{c}\text { Nilai } \\
\text { Terendah }\end{array}$ & $\begin{array}{c}\text { Nilai } \\
\text { Tertinggi }\end{array}$ & $\begin{array}{c}\text { Simpang } \\
\text { Baku }\end{array}$ & Range \\
\hline $\begin{array}{l}\text { Sebelum } \\
\text { Pendidikan }\end{array}$ & 4,46 & 0 & 10 & 2,38 & 10 \\
\hline $\begin{array}{l}\text { Sesudah } \\
\text { Pendidikan }\end{array}$ & 13,97 & 4 & 20 & 4,99 & 16 \\
\hline
\end{tabular}

Secara deskriptif perbedaan antara pengetahuan sebelum dan sesudah diberikan pendidikan kesehatan dapat disimak pada tabel 2 bahwa ada peningkatan nilai rata-rata pengetahuan dari 4,46 menjadi 13,97 dari nilai maksimal 20. Hasil ini sesuai dengan penelitian yang dilakukan oleh Priwanci (2010) yang menunjukkan adanya efek pendidikan kesehatan tentang hipertensi stadium 1 terhadap peningkatan pengetahuan keluarga dalam menjalankan 5 tugas kesehatan keluarga di wilayah kerja Puskesmas Mojo secara signifikan.

\section{Sikap tentang Hipertensi}

Sikap adalah reaksi atau respon seseorang yang masih tertutup terhadap suatu stimulus atau objek, manifestasi sikap tidak dapat langsung dilihat tetapi hanya dapat ditafsirkan terlebih dahulu dari perilaku yang tertutup. Sikap juga merupakan reaksi yang bersifat emosional terhadap stimulus sosial (Notoatmodjo, 2003).

Tabel 3.

Deskripsi Data Skor Sikap

\begin{tabular}{|l|c|c|c|c|c|}
\hline \multicolumn{1}{|c|}{ Kondisi } & $\begin{array}{c}\text { Rata- } \\
\text { rata }\end{array}$ & $\begin{array}{c}\text { Nilai } \\
\text { Terendah }\end{array}$ & $\begin{array}{c}\text { Nilai } \\
\text { Tertinggi }\end{array}$ & $\begin{array}{c}\text { Simpang } \\
\text { Baku }\end{array}$ & Range \\
\hline $\begin{array}{l}\text { Sebelum } \\
\text { Pendidikan }\end{array}$ & 3,49 & 0 & 11 & 3,24 & 11 \\
\hline $\begin{array}{l}\text { Sesudah } \\
\text { Pendidikan }\end{array}$ & 9,90 & 1 & 15 & 4,22 & 14 \\
\hline
\end{tabular}

Perbedaan antara sikap sebelum dan sesudah diberikan pendidikan kesehatan dapat digambarkan secara deskriptif seperti pada tabel 3 yakni ada peningkatan nilai ratarata sikap dari 3,49 menjadi 9,90 dari nilai maksimal 15. Hasil ini sesuai dengan pene- litian yang dilakukan oleh Priwanci (2010) yang menunjukkan adanya efek pendidikan kesehatan tentang hipertensi stadium 1 terhadap peningkatan sikap keluarga dalam menjalankan 5 tugas kesehatan keluarga di wilayah kerja Puskesmas Mojo secara signifikan

Menurut Notoatmodjo (2003), pengetahuan dan sikap seseorang dipengaruhi oleh beberapa faktor yaitu tingkat pendidikan, komunikasi dan informasi, kebudayaan, dan pengalaman pribadi secara emosional. Mekanisme adanya perbedaan pengetahuan dan sikap secara bermakna ini disebabkan adanya faktor informasi dan komunikasi yang mempengaruhi pembentukan pengetahuan dan sikap. Informasi yang diberikan langsung maupun tidak langsung mempunyai pengaruh dalam peningkatan pengetahuan, pembentukan opini dan kepercayaan orang. Di bidang kesehatan informasi dapat diperoleh melalui tatap muka langsung dengan penyampai informasi seperti petugas kesehatan, tokoh masyarakat, tokoh agama serta aparat pemerintah yang mendukung serta dapat diperoleh melalui berbagai media massa seperti radio, televisi, majalah, surat kabar dan lain-lain. Adanya informasi baru mengenai sesuatu hal akan memberikan landasan kognitif bagi terbentuknya sikap terhadap hal tersebut (Maulana, 2009). Ragam pesan subjektif yang dibawa oleh informasi tersebut cukup kuat dan memberikan dasar afektif dalam menilai sesuatu hal sehingga terbentuklah arah sikap tertentu (Suliha, 2002).

Pemberian informasi tentang kebiasaan hidup sehat dan cara-cara mencegah penyakit diharapkan akan terjadi peningkatan pengetahuan, sikap dan perilaku kesehatan dalam diri/kelompok sasaran yang berdasarkan kesadaran dan kemauan individu yang bersangkutan. Perubahan perilaku ini memang memakan waktu yang lama, sebab tidak sekedar melibatkan perubahan gerakan/ aktivitas motorik, melainkan menyangkut pula perubahan persepsi tentang konsep- 
konsep kesehatan dan perubahan sikap terhadap tindakan yang dianjurkan. Walaupun lebih lama, namun ternyata hasil perubahan yang dicapai lebih lama dan lestari dan tidak tergantung dari ketatnya pengawasan (Sarwono, 2004)

Data Kementrian Koordinator Bidang Kesehatan Rakyat Kedeputian I Bidang Kesejahteraan Sosial tahun 2009 menyatakan bahwa terdapat kenaikan usia harapan hidup di Indonesia yang disebabkan oleh peningkatan tingkat sosial ekonomi, kenaikan tingkat kesehatan dan tingkat pengetahuan masyarakat. Adanya pendidikan kesehatan tentang hipertensi yang diberikan secara berkesinambungan dan proporsional diharapkan mampu memperbaiki pola hidup lansia dan meluruskan mitos-mitos yang salah karena kurang cukupnya informasi yang didapatkan. Pendidikan kesehatan tentang hipertensi diharapkan dapat mengubah pengetahuan, pemahaman dan sikap serta perilaku lansia terhadap kesehatannya sehingga lansia dapat menjalankan pola hidup sehat dan angka kejadian penyakit kardiovaskuler akan menurun.

\section{SIMPULAN DAN SARAN}

Berdasarkan hasil kegiatan yang dilakukan, dapat disimpulkan terdapat peningkatan nilai rerata pengetahuan tentang hipertensi setelah pemberian pendidikan dari
4,46 menjadi 13,97 dan rerata sikap tentang hipertensi dari 3,49 menjadi 9,90.

Saran untuk pihak posyandu lansia, diharapkan hasil pengabdian ini dapat ditindaklanjuti dengan terus mengupayakan program pendidikan kesehatan terutama masalah penyakit degeneratif untuk meningkatkan kesejahteraan dan kesehatan lansia. Sedangkan bagi instansi terkait, hasil penelitian ini diharapkan memberikan masukan kepada instansi pemegang kebijakan pembangunan kesehatan seperti Dinas Kesehatan untuk meluaskan sasaran penyuluhan kesehatan pada lansia dengan memanfaatkan program-program kesehatan bagi lansia melalui Puskesmas

\section{PERSANTUNAN}

Pada kesempatan ini kami menyampaikan terima kasih kepada pihakpihak yang terkait, kepada bapak Rektor UMS melalui Lembaga Pengabdian Masyarakat yang telah berkenan membiayai sehingga kegiatan ini berjalan dengan baik. Kepada Dekan Fakultas Kedokteran UMS yang turut memperlancar kegiatan ini, kepada Kepala Desa Makamhaji, Ketua Posyandu Lansia Dukuh Gantungan dan kader Posyandu Lansia Dukuh Gantungan Makamhaji Kartasura Sukoharjo yang telah membantu sehingga kegiatan ini dapat berjalan dengan lancar.

\section{DAFTAR PUSTAKA}

Adrogué H J dan Madias Nicolaos E. 2007. Sodium and Potassium in the Pathogenesis of Hypertension. NEJM; 356:1966-1978

August, Phyllis. 2007. Initial Treatment of Hypertension. NEJM; 348; 610-617

Braunwald, E., A. S. Fauci., D.L.,Kasper., S.L.Hauser., D.L.Longo., J.L.Jameson. 2001. “Harrison's Mannual of Medicine $15^{\text {th }}$ edition”. USA: Mc Draw-Hill Profesional

Cunha, Maria G. 2001. Usia Lanjut di Indonesia: Potensi, Masalah, Kebutuhan (Suatu Kajian Literatur). Disitasi dari www. atmajaya.ac.id/content asp. Diakses tanggal 2 Oktober 2009 
Data Statistik Indonesia. 2010. Disitasi dari http://www.datastatistik-indonesia.com. Diakses tanggal 2 Oktober 2009

Fisher, NDL dan Gordon, H William. 2005. Hypertensive Vascular Disease dalam Harrison's principles of Internal Medicine $16^{\text {th }}$ edition. USA: Mc Graw-Hill Profesional

Kementrian Koordinator Bidang Kesehatan Rakyat Kedeputian I Bidang Kesejahteraan Sosial. 2009. Lansia Masa Kini dan Mendatang. www. Situs resmi kemetrian koordinator bidang kesejajtaraan rakyat. Diakses tanggal 2 October 2009

Kiger, Alice M. 2004. Teaching for Health. London: Churchill Livingstone

Maulana, Heri DJ. 2009. Promosi Kesehatan. Jakarta: Penerbit Buku Kedokteran EGC

Megarani, AM. 2007. Pada 2025, Seperlima Penduduk Indonesia Lansia. www. Tempointeraktif.com. Diakses tanggal 2 Oktober 2009

National Heart Lung \& Blood Insitute. 2003. The seventh report of Joint National Committee on Prevention, Detection, Evaluation, and Treatment of High Blood Pressure dalam The JNC VII report. Disitasi dari: http://www.nhlbi.nih.gov/guidelines/hipertensi/ JNC 7 full / htm. Diakses tanggal 2 Oktober 2009.

Notoatmodjo, S. 2003. Pendidikan dan Perilaku Kesehatan. Jakarta: Rineka Cipta

Nugroho, Wahyudi. 2000. Keperawatan Gerontologi. Jakarta: EGC

Priwanci, Indar. 2010. Pengaruh Pendidikan Kesehatan tentang Hipertensi Stadium 1 terhadap Pengetahuan dan Sikap Keluarga dalam Menjalankan 5 Tugas Kesehatan Keluarga di Wilayah Kerja Puskesmas Mojo. SKRIPSI. Universitas Airlangga. Surabaya. Disitasi dari http: alumni.unaiir.ac.id/kumpulan file/ 1856829790_abs.pdf

Sarwono, Solita. 2004. Sosiologi Kesehatan Beberapa Konsep Beserta Aplikasinya. Yogyakarta: Gadjah Mada University Press

Suliha U. 2002. Pendidikan Kesehatan Dalam Keperawatan. Jakarta: Penerbit Buku Kedokteran EGC 